\title{
Demokrasi dalam Masyarakat
}

Mukhammad Fakhrizal Baihaqi

IIK STRADA INDONESIA

baihaqifakhrizal@gmail.com

\begin{abstract}
Abstrak
Demokrasi di dunia memiliki sejarahnya sendiri dimulai dari pertengahan abad 5 SM, istilah demokrasi untuk menunjukkan sistem politik yang ada di beberapa negara-kota Yunani, terutama di Athena. Banyak sekali ketidak tahuan masyarakat akan pentingnya mengetahui demokrasi. Setidaknya tahu akan apa aitu artinya demokrasi, sehingga ketika adanya suaatu pemilihan maka bisa memilih dengan bijak. Solusi yang tepat adalah mempelajari dari arti demokrasi itu sendiri.
\end{abstract}

\section{Latar Belakang}

Demokrasi di dunia memiliki sejarahnya sendiri dimulai dari pertengahan abad 5 SM, istilah demokrasi untuk menunjukkan sistem politik yang ada di beberapa negara-kota Yunani, terutama di Athena (Arum Sutrisni Putri, 2020). Di Indonesia sendiri sudah dimualai pada 1945 dimana pertama kali dilakukan demokrasi yaitu demokrasi parlementer. Sejak saat itu demokrasi mulai dijalankan dan masyarakat sekitar dijadikan sebagai penentu roda demokrasi di Indonesia ini. Sebagai masyarakat kita sebaiknya benar-benar paham apa arti dari demokrasi sendiri agar tidak salah pilih yang akhirnya berakhir ketidak puasan dari suatu kebijakan yang telah disetujui dan diterapkan oleh pemerintah.

Demokrasi di Indonesia sendiri sudah beberapakali mengalami perubahan dan disesuaikan. Banyak sekali tokoh-tokoh yang memeliki arti demokrasi sendiri-sendiri, dan dapat diketahui bahwa demokrasi sendiri juga tergantung oleh rakyat itu sendiri yang dapat memilih bebas para pemimpin untuk memimpin negeri.

\section{Masalah}

Banyak sekali ketidak tahuan masyarakat akan pentingnya mengetahui demokrasi. Setidaknya tahu akan apa aitu artinya demokrasi, sehingga ketika adanya suaatu pemilihan maka bisa memilih dengan bijak. 


\section{Tinjauan Pustaka}

(Purnamawati, 2020)PERJALANAN DEMOKRASI DI INDONESIA. Membahas tentang sejarah demokrasi di Indonesia. Memiliki kesamaan yaitu membahas sejarah demokrasi di Indonesia.

(Noviati, 2013) Demokrasi dan Sistem Pemerintahan. Membahas tentang demokrasi dan sistem pemerintahan. Memiliki kesamaan yaitu membahas tentang demokrasi.

\section{Pembahasan}

Demokrasi sendiri merupakan sistem pemerintahan dari rakyat, untuk rakyat, dan oleh rakyat, dimana setiap orang dapat mengambil bagian perihal keputusan yang akan mempengaruhi kehidupannya dalam bernegara (Ahmad). Dalam buku berjudul Komunikas Politik, Media \& Demokrasi dari Henry Subiakto dijabarkan latar belakang, pendekatan, metode stutdi komunikasi politik, komunikasi politik dan kepemimpinan politik yang akan membentuk demokrasi itu sendiri. Demokrasi berasal dari bahasa Yunani yaitu "Demos" dan "Kratos". Demos bermakna rakyat atau khalayak, sementara Kratos bermakna pemerintahaan. Demokrasi sebagai sistem pemerintahan yang mengijinkan dan memberikan hak, kebebasan kepada warga negaranya untuk berpendapat serta turut serta dalam pengambilan keputusan di pemerintahan.

Sementara itu demokrasi di Indonesia sendiri memeliki sekarahnya sendiri, dalam buku yang berjudul Ilmu Negara jika berbicara tentang sejarah teori demokrasi, ada 2(dua) fakta historis yang penting. Pertama, hampir semua orang pada masa ini mengaku sebagai demokrat. Beragam jenis rezim politik di dunia mendeskripsikan dirinya sebagai demokrasi. Namun, apa yang dikatakan dan diperbuat oleh rezin yang satu dengan rezim yang lain sering berbeda secara substansial.

Kedua, sementara banyak negara yang saat ini menganut paham demokrasi, sejarah lembaga politiknya mengungkap adanya kerapuhan dan kerawanan tatanan demokrasi. Sejarah Eropa Abad ke-20 sendiri mengambarkan dengan jelas bahwa demokrasi merupakan bentuk pemerintahan yang sangat sulit untuk diwujudkan dan dijaga. (Huda, 2010),

(Novi Fuji Astuti, 2020) Perkembangan demokrasi di Indonesia :

1. Demokrasi Parlementer (1945-1959)

Demokrasi di Indoensia yang pertama adalah demokrasi parlementer yang menonjolkan peranan parlementer serta partai-partai. Akibatnya, persatuan yang digalang selama perjuangan melawan musuh bersama menjadi kendor dan tidak dapat dibina menjadi kekuatan konstruktif 
sesudah kemerdekaan. Sistem parlementer ini mulai berlaku sebulan sesudah kemerdekaan diproklamirkan dan kemudian diperkuat dalam Undang-Undang Dasar 1945 dan 1950.

2. Demokrasi Terpimpin (1959-1965)

Demokrasi di Indonesia berikutnya adalah demokrasi terpimpin. Demokrasi terpimpin ini telah menyimpang dari demokrasi konstitusional dan lebih menampilkan beberapa aspek dari demokrasi rakyat. Masa ini kuat ditandai dengan dominasi presiden, terbatasnya peran partai politik, perkembangan pengaruh komunis dan peran ABRI sebagai unsur sosial-politik semakin meluas. UUD 1945 membuka kesempatan bagi seorang presiden untuk bertahan selama sekurang-kurangnya lima tahun. Namun ketetapan MPRS No. III/1963 yang mengangkat Ir. Soekarno sebagai presiden seumur hidup telah membatalkan pembatasan waktu lima tahun ini yang ditentukan oleh Undang-Undang Dasar.

3. Demokrasi Pancasila era orde baru (1965-1998)

Demokrasi pancasila merupakan demokrasi konstitusional yang menonjolkan sistem presidensial. Landasan formal periode ini adalah pancasila, UUD 1945, dan Tap MPRS/MPR dalam rangka meluruskan penyelewengan terhadap UUD 1945 yang terjadi pada masa demokrasi terpimpin. Namun, dalam perkembangannya peran presiden justru semakin dominan terhadap lembaga-lembaga Negara yang lain.Melihat praktik demokrasi pada masa ini, nama pancasila hanya digunakan sebagai legitimasi politik penguasa pada saat itu. Sebab kenyataannya yang dilaksanakan tidak sesuai dengan nilai-nilai Pancasila.Demokrasi Pancasila pada era Orde Baru kerap ditandai dengan dominasi peran ABRI, Birokratisasi dan sentralisasi pengambilan keputusan politik, pengebirian peran dan fungsi partai politik, campur tangan pemerintah dalam berbagai urusan partai politik dan publik, masa mengambang, monolitisasi ideologi negara, inkorporasi lembaga non pemerintah. Pemerintahan Orde Baru sendiri berakhir pada tahun 1998 setelah Soeharto dilengserkan oleh rakyatnya pada Mei 1998.

4. Demokrasi Pancasila era Reformasi (1998-sekarang)

Setelah Orde Baru berakhir, Indonesia mulai memasuki era Reformasi di mana pemerintah Habibie mulai menjalankan demokrasi dengan menyuburkan kembali alam demokrasi di Indonesia dengan jalan kebebasan pers dan kebebasan berbicara. Keduanya dapat berfungsi sebagai check and balances serta memberikan kritik supaya kekuasaan yang dijalankan tidak menyeleweng terlalu jauh. Dalam perkembangannya demokrasi di Indonesia setelah rezim Habibie diteruskan oleh presiden Abdurahman Wahid sampai dengan Pemerintahan Joko Widodo.

Karakteristik negara demokratis menurut situs resmi Kementrian Pendidikan dan Kebudayaan RI :

1) Persamaan kedudukan di depan hukum

Persamaan kedudukan di muka hukum Hukum mengatur bagaimana seharusnya penguasa bertindak, bagaimana hak dan kewajiban dari penguasa dan juga rakyatnya. Semua rakyat 
memiliki kedudukan sama di depan hukum. Artinya, hukum harus dijalankan secara adil dan benar. Hukum tidak boleh pandang bulu. Siapa saja yang bersalah dihukum sesuai ketentuan yang berlaku. Untuk menciptakan hal itu harus ditunjang dengan adanya aparat penegak hukum yang tegas dan bijaksana. Serta bebas dari pengaruh pemerintahan yang berkuasa dan berani menghukum siapa saja yang bersalah.

2) Partisipasi dalam pembuatan keputusan

Hukum mengatur bagaimana seharusnya penguasa bertindak, bagaimana hak dan kewajiban dari penguasa dan juga rakyatnya. Semua rakyat memiliki kedudukan sama di depan hukum. Artinya, hukum harus dijalankan secara adil dan benar. Hukum tidak boleh pandang bulu. Siapa saja yang bersalah dihukum sesuai ketentuan yang berlaku. Untuk menciptakan hal itu harus ditunjang dengan adanya aparat penegak hukum yang tegas dan bijaksana. Serta bebas dari pengaruh pemerintahan yang berkuasa dan berani menghukum siapa saja yang bersalah.

3) Distribusi pendapatan secara adil

Di negara demokrasi, semua bidang dijalankan berdasarkan prinsip keadilan termasuk di bidang ekonomi. Semua warga negara berhak memperoleh pendapatan yang layak. Pemerintah wajib memberikan bantuan pada kepada fakir dan miskin yang berpendapatan rendah. Sehingga diharapkan terjadi distribusi pendapatan yang adil di antara warga negara Indonesia. Contoh, pemerintah giat membuka lapangan kerja agar masyarakat bisa memperoleh penghasilan.

4) Kebebasan yang bertanggung jawab

Dalam sebuah negara yang demokratis terdapat empat kebebasan yang penting, yaitu: Kebebasan beragama, Kebebasan pers, Kebebasan mengeluarkan pendapat, Kebebasan berkumpul .Empat kebebasan tersebut adalah HAM yang harus dijamin keberadaannya oleh negara. Akan tetapi dalam pelaksanaannya mesti bertanggung jawab. Artinya kebebasan yang dimiliki oleh setiap warga negara tidak boleh bertentangan dengan norma-norma yang berlaku. Kebebasan yang dikembangkan adalah kebebasan yang tidak tak terbatas. Yaitu kebebasan yang dibatasi oleh aturan dan kebebasan yang dimiliki oleh orang lain.

Bila kehidupan tidak demokratis maka asas kedaulatan rakyat tidak berjalan, tidak ada jaminan HAM, tidak ada persamaan di depan hukum. Bila demikian, maka tujuan mewujudkan masyarakat adil dan Makmur berdasarkan Pancasila akan semakin jauh. Oleh sebab itu masyarakat sendiri perlu mengetahui tentang demokrasi ini.

\section{Kesimpulan}

Kita sebagai masyarakat seharunsnya dapat mengetahui tentang demokrasi yang ada di Indonesia ini agar kita dapat menentukan pemertintah yang akan memimpin masa depan bangsa. Dengan adanya demokrasi sendiri kita sebagai masyarakat bebas memilih calon pemipin bangsa dan juga dapat berpartispasi dalam pembuatan kebijakan pemerintah. 


\section{Daftar Pustaka}

Ahmad, G. B. (n.d.). Pengertian Demokrasi: Sejarah, Ciri, Tujuan, Macam dan Prinsip. Retrieved from Gramedia Blog .

Arum Sutrisni Putri, K. (2020, 01 21). Demokrasi: Pengertian, Sejarah Singkat dan Jenis.

Huda, N. (2010). Ilmu Negara.

Novi Fuji Astuti, m. (2020, 11 03). Macam-macam Demokrasi di Indonesia, dari Parlementer hingga Pancasila.

Purnamawati, E. (2020). PERJALANAN DEMOKRASI DI INDONESIA , 251-264.

Puslit IAIN Syarif Hidayatullah. (2000). Pendidiakan Kewarganegaraan Masyarakat Madani.

Baihaqi, M. F. (2021). Sampah Pembawa Penyakit Bagi Masyarakat. 